\title{
Pinellia ternata agglutinin produced in Bombyx mori cells exhibits bioactivity
}

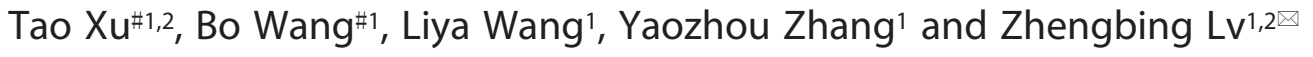 \\ ${ }^{1}$ College of Life Sciences, Zhejiang Sci-Tech University, Hangzhou, China; ${ }^{2}$ Silkworm Bioreactor and Key Laboratory of Biologic Medicine \\ of Zhejiang Province, China
}

\begin{abstract}
Pinellia ternata agglutinin (PTA) is highly homologous to many other monocot mannose-binding lectins which reportedly possess antitumor activities. Its production in silkworm cells has great application potential because the baculovirus expression system can produce posttranslationally modified proteins at low cost. In the current study, the pta gene was cloned and expressed in silkworm cells, and the expressed protein was analyzed using a hemagglutination assay. A preliminary in vitro study on its anti-proliferative activity was performed. The results show that the recombinant PTA with an apparent molecular mass of $29 \mathrm{kDa}$ can hemagglutinate rabbit erythrocytes and this activity can be inhibited by D-mannan at a low concentration. In addition, the recombinant hemagglutinin exhibited a dose-dependent anti-proliferative activity on hepatoma cells. The results of the current study suggest that PTA and other important bioactive proteins could be produced by silkworm bioreactor for biomedicine research and application.
\end{abstract}

Keywords: Pinellia ternata agglutinin, plant lectin, Bombyx mori cells, silkworm bioreactor

Received: 29 July, 2011, revised: 12 January, 2012; accepted: 04 April, 2012; available on-line: 18 May, 2012

\section{INTRODUCTION}

Plant lectins belong to a very heterogeneous group of glycoproteins that recognize and bind to polysaccharides or glycoproteins on cell surfaces. They are widespread in dicotyledonous and monocotyledonous plants (Kaku et al., 1990; Hamelryck et al., 1999; Mo et al., 1999). These lectins are widely used in studies on biochemistry, cell biology, immunology, glycobiology, and biomedicine (Sharon \& Lis, 2004). In recent years, several plant lectins have been reported to possess marked cytotoxic activity and to induce apoptosis in many typical tumor cells (Karasaki et al., 2001; De Mejía, 2005; kaur et al., 2006). Wheat germ agglutinin, concanavalin $\mathrm{A}$ and phytohemagglutinin reportedly have inhibitory effects on colorectal cancer cell lines (Abdullaev \& Gonzalez, 1997). They are excellent candidates in cancer research and therapy (Rostock et al., 2005; Liu et al., 2010).

Most lectins from monocotyledonous plants notably belong to a single monocot mannose-binding superfamily, as revealed by their molecular evolution, physiologic roles, sequence homologies, and specificity for mannose or mannoside. Given their unique carbohydrate-binding properties, these lectins have become widely used in biochemical and pharmacological research (Barre et al., 1996). In contrast to other lectins, those from the Ar- aceae family exhibit either very weak or no affinity for monosaccharides, disaccharides, or oligosaccharides, whereas they bind to glycans or glycoproteins with great affinity (Van et al., 1995; Bains et al., 2005; Ling et al., 2010). A number of lectins from this family reportedly possess anti-tumor activity which depends on their mannose-binding activity (Trigueros et al., 2000). For instance, Arisaema jacquemontii lectin has appreciable inhibitory effect on the in vitro proliferation of ten human cancer cell lines (Kaur et al., 2006). Typhonium divaricatum lectin showed anti-proliferative activity towards some wellestablished cancer cells such as prostatic carcinoma, lung cancer, and mastocarcinoma (Luo et al., 2007). Furthermore, lectins from Arisaema flavum, Arisaema belleborifolium, Acorus tatarinowii, Sauromatum venosum, and so on reportedly have anti-proliferative effects on cancer cell lines in vitro (Singh \& Kamboj, 2004; Bains et al., 2005; SinghBains et al., 2005; Kaur et al., 2006; Luo et al., 2007). In addition, many studies have suggested that most lectins from the Araceae family are glycoproteins, such as those from A. jacquemontii, Arisaema tortuosum, A. belleborifolium, and so on because they have been proven to contain carbohydrates (Dhuna et al., 2005; Kaur et al., 2006; Kaur et al., 2006). The amino acid sequences of the Araceae lectins including Pinellia ternata agglutinin (PTA) are well conserved. PTA from $P$. ternata (Thunb) Breit, an important Araceae herb in traditional Chinese medicine, has been widely used to treat diseases including cancers (Wong \& Sagar, 2010). It is a homotetramer composed of four non-covalently bonded $12 \mathrm{kDa}$ monomers with twelve well-exposed functional mannose-binding sites, which is designated as a GNA-related lectin (Van et al., 2007). P. ternata resources have become sparse because of deterioration of the environment. Therefore, acquiring substantial amounts of high-quality native PTA is difficult. Remarkably, there is a report suggesting that the activity of recombinant PTA is relatively higher than that of native PTA (Ling et al., 2010). At present, recombinant PTA generated using genetic engineering is mainly expressed in Escherichia coli. However, this recombinant PTA is incorrectly folded and lacks post-translational modifications.

Bombyx mori, one of the most genetically exploited insects, has a well-studied genetic background (Xia et al., 2004; Consortium, 2008). As it is susceptible to nuclear polyhedrosis virus infection, many studies have reported successful use of B. mori as a bioreactor for the production of recombinant proteins using the $B$. mori nucleopolyhedrovi-

e-mail: zhengbingl@zstu.edu.cn

\#These authors contributed equally to this work

Abbreviations: rPTA: recombinant Pinellia ternata agglutinin; TEM: transmission electron microscope; BmNPV: Bombyx mori nucleopolyhedrovirus. 
rus (BmNPV) expression system (Inoue et al., 2005). For instance, mature human granulocyte macrophage colony stimulating factor (hGM-CSF) was successfully expressed in B. mori, and its biological activity was the same as of the native one (Chen et al., 2006). One of the major advantages of the BmNPV expression system is that it can be used to produce relatively large quantities of posttranslationally modified heterologous proteins. Given that the Bac-to-Bac/BmNPV expression system is inexpensive, convenient, and has a high level of production, it has been widely used to express recombinant proteins (Miao et al., 2006; Yue et al., 2006; Zhou et al., 2009; Li et al., 2010).

In the current study, the pta gene from tubers of virus-free cultured $P$. ternata was cloned; a baculovirus containing the cloned gene was constructed and successfully expressed in B. mori cells. The agglutination activity of the purified protein on rabbit erythrocytes was higher than when it was expressed in E. coli (Ling et al., 2010). The recombinant PTA revealed antiproliferative activity against human hepatoma cells in vitro. The results of this study suggest that the $B$. mori expression system has great potential for manufacturing plant lectins for indepth research and application.

\section{MATERIALS AND METHODS}

Materials. Tubers of $P$. ternata (Thunb) Breit were obtained from the plant laboratory of Zhejiang SciTech University, Zhejiang, China. B. mori cells were cultured in Grace's medium (Invitrogen) supplemented with $10 \%(\mathrm{v} / \mathrm{v})$ fetal bovine serum (FBS, Invitrogen) at $27^{\circ} \mathrm{C}$. DNA primers were synthesized by Sangon BiotechCo., Ltd (Shanghai). A DNA purification system was purchased from Axygen. Bac-to-Bac baculovirus expression system was purchased from Invitrogen. EZ-ECL Chemiluminescence Detection Kit for HRP was purchased from Multisciences Biotech Co., Ltd. X-OMATBT film was purchased from Kodak. Antibodies were purchased from Beyotime. Other chemical reagents were from commercial sources and were all of analytical grade.

Cloning of pta and construction of a recombinant vector. Reverse transcriptase polymerase chain reaction (RT-PCR) was performed to clone the pta gene from total RNA extracted from the $P$. ternata tubers using Trizol reagent (Invitrogen). Two PCR primers were designed: sense: 5'-GGACCATGGATGGCCTCCAAGCTCCTCC-3'; antisense: 5'-GGACTCGAGCTACGCAGCAATGGAGCGC-3' with $N c o \mathrm{I}$ and XhoI restriction sites introduced before the start codon and after the stop codon, respectively. After synthesizing the first-strand cDNA at $55^{\circ} \mathrm{C}$ for $30 \mathrm{~min}$ and at $85^{\circ} \mathrm{C}$ for $5 \mathrm{~min}, \mathrm{PCR}$ was performed at $94^{\circ} \mathrm{C}$ for $3 \mathrm{~min}$, then 30 cycles of $94^{\circ} \mathrm{C}$ for $30 \mathrm{~s}, 62^{\circ} \mathrm{C}$ for $30 \mathrm{~s}, 72^{\circ} \mathrm{C}$ for $1 \mathrm{~min}$, and lastly, $72^{\circ} \mathrm{C}$ for $10 \mathrm{~min}$. The PCR product was gelpurified and digested with $N c o I$ and XhoI. Then, it was inserted into the donor plasmid pFastBacHTA. The resultant pFastBacHTA-pta, which was identified by PCR and sequenced using ABI-PRISM 3730 Genetic Analyzer, was transformed into $E$. coli $\mathrm{DH} 10 \mathrm{Bac}$ competent cells. A recombinant bacmid was generated. Then, the recombinant bacmid (rbacmid) was isolated from the transformant, which was screened by resistance to kanamycin, tetracycline, and gentamicin and by blue-white selection with 5-bromo-4-chloro-3-indolyl-beta-D-galactoside (X-gal) and isopropyl-beta-D-thiogalactopyranoside (IPTG) on LB agar plates.
Construction of recombinant baculovirus. Approximately $3 \times 10^{5} \mathrm{~B}$. mori cells were seeded into a sixwell cell culture plate containing complete growth media. The cells were then cultured for $24 \mathrm{~h}$. For transfection, the B. mori cells were washed with unsupplemented Grace's medium and maintained in the same medium. Lipid-rbacmid complex prepared according to the manual of cellfectin reagent was added directly to the cells. After incubation for $6 \mathrm{~h}, 1 \mathrm{~mL}$ of complete growth media was added and the cells were incubated for another 36$120 \mathrm{~h}$. The recombinant baculovirus was harvested from the cell supernate and stored at $4^{\circ} \mathrm{C}$ in the dark. M13 forward and reverse primers, as well as PCR primers were designed and used to verify the recombinant virus.

Expression of recombinant PTA in $B$. mori cells. Previously prepared recombinant baculovirus stock $\left(10^{6} p f u / \mathrm{mL}\right)$ was inoculated into B. mori cells in the midlogarithmic phase of growth at a density of $1 \times 10^{6}-2 \times 10^{6}$ cells $/ \mathrm{mL}$. Then, the cultured cells were placed in a humidified incubator for 4 days at $27^{\circ} \mathrm{C}$, and viewed under an inverted phase-contrast microscope.

Detection of expressed protein using Western blotting. After the B. mori cells were suspended from the plate, the cells were gathered, boiled with $2 \times$ isopyknic loading buffer for $3 \mathrm{~min}$, and analyzed on a $12 \%$ SDS/ PAGE gel. The proteins were transferred onto a polyvinylidene fluoride membrane, and the membrane was blocked for $2 \mathrm{~h}$ using 3\% nonfat dry milk in Tris-buffered saline with $0.1 \%$ Tween-20, incubated overnight in $1000 \times$ diluted $6 \times$ His antibody, followed by $1 \mathrm{~h}$ incubation with horseradish peroxidase-labeled rat anti-IgG antibodies, and washed with Tris-buffered saline. The antibodies were detected using EZ-ECL Chemiluminescence Detection kit and exposure to X-ray film.

Purification of the expressed protein. Suspended cells were collected and resuspended in ice-cold lysis buffer $(50 \mathrm{mM} / \mathrm{L}$ Tris/ $\mathrm{HCl}, 5 \mathrm{mM} / \mathrm{L}$ mercaptoethanol, $100 \mathrm{mM} / \mathrm{L} \mathrm{KCl}, 1 \mathrm{mM} / \mathrm{L}$ PMSF, and 1\% NP-40 at $\mathrm{pH}$ 8.0). After ultrasonication, the lysate was centrifuged at $10000 \mathrm{rpm}$ for $10 \mathrm{~min}$ at $4^{\circ} \mathrm{C}$. The His-tagged protein was purified from the recovered supernates using HisPur Ni-NTA Resin and kits (Thermo). The target protein was concentrated and the solvent was displaced using Millipore AmiconUltra-15 ultrafiltration centrifugal tube with a $10 \mathrm{kDa}$ cut-off. Then, the protein was dissolved in $0.9 \%$ sodium chloride solution for subsequent experiments.

Protein analysis using mass spectrometry. Purified rPTA was subjected to $12 \%$ SDS/PAGE, stained with bromophenol-blue, the band of $29 \mathrm{kDa}$ was cut from the gel and digested in-gel with trypsin according to the methods described by Shevchenko et al. The MS and MS/MS spectra were recorded using a 4700 proteomics Analyzer MALDI-TOF/TOF mass spectrometer (Applied Biosystems, Foster City, CA) according to the methods described by Gao et al.

Hemagglutination activity and saccharide inhibition assay. The hemagglutination activity of the recombinant PTA was assayed in 96-well microtiter plates according to the serial double dilution method using rabbit erythrocytes. The process was adopted from previously described methods (Singh \& Kamboj, 2004). Inhibition of hemagglutination by carbohydrates was carried out by a twofold serial dilution technique.

Assay of in vitro anti-proliferative potential of rPTA on human cancer cell line. Treatment of cells with recombinant PTA. Human hepatoma SMMC7721 cells were inoculated at a density of $1 \times 10^{5}$ cells $/ \mathrm{mL}$ into cell culture plates and incubated for $24 \mathrm{~h}$. The 


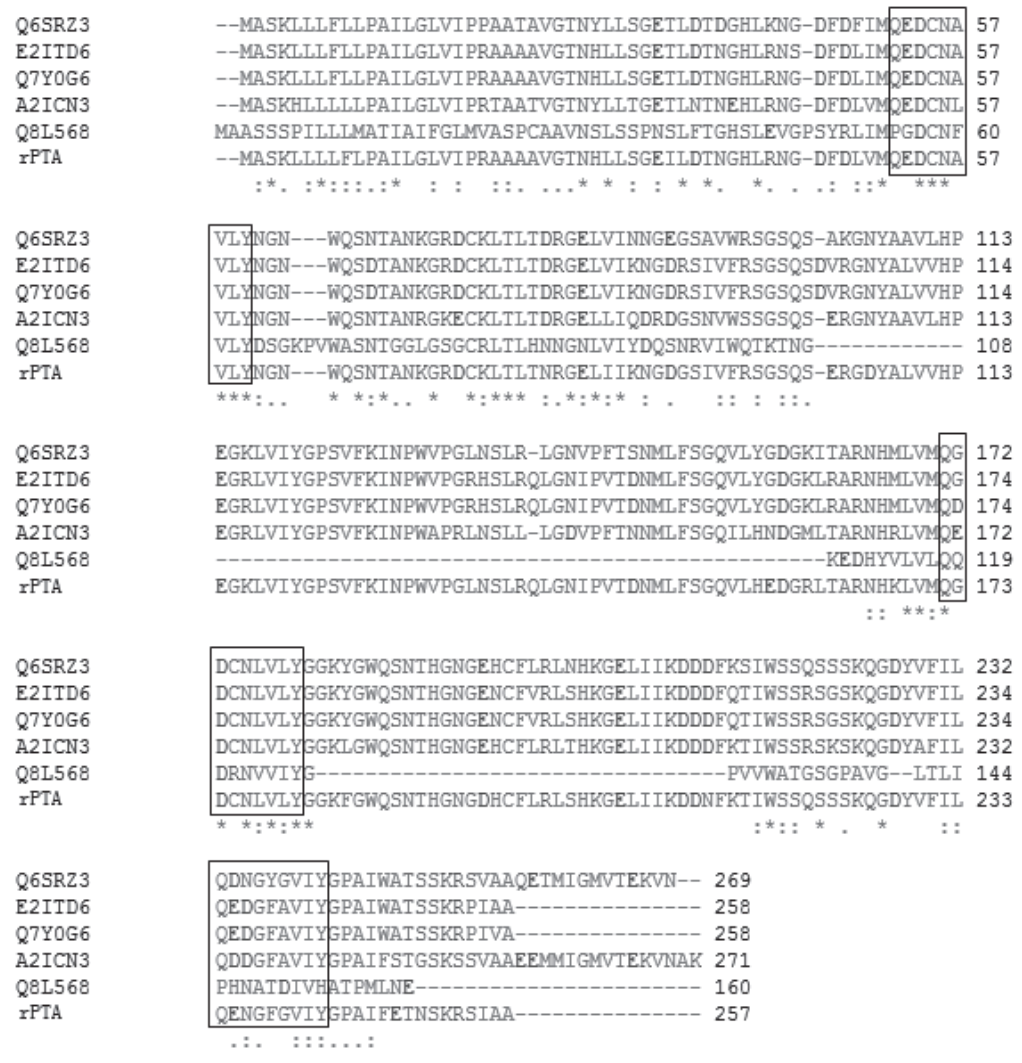

Figure 1. Multiple alignment of predicted Pinellia ternata agglutinin (PTA) amino acid sequence with some other mannose-binding lectins.

DB: ID Q6SRZ3 (Previously sequenced PTA), DB: ID E2ITD6 (Pinellia pedatisecta agglutinin), DB: ID Q7Y0G6 (Arisaema heterophyllum agglutinin), DB: ID A2ICN3 (Typhonium divaricatum lectin) and DB: ID Q8L568 (Polygonatum cyrtonema lectin). Mannose-binding sites (QXDXNXVXY) are boxed.

recombinant PTA dissolved in $0.9 \%$ sodium chloride solution was added into the plates at different final protein concentrations. Control cells were treated with $0.9 \%$ sodium chloride solution. All the cultures were incubated at $37^{\circ} \mathrm{C}$ with $5 \% \mathrm{CO}_{2}$ for $48 \mathrm{~h}$.

Ultrastructure observation. Cells from the $40 \mu \mathrm{g} /$ $\mathrm{mL}$ recombinant PTA treatment and control groups were fixed with glutaraldehyde and osmium tetroxide. Then, the cells were dehydrated, passed through epoxy propane, and infiltrated with araldite epoxy resin. The polymerized sample was thin-sectioned on an ultrami-

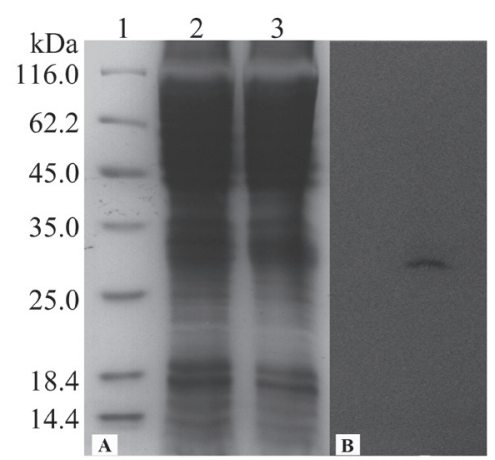

Figure 2. SDS/PAGE and Western blot analysis of proteins produced in $B$. mori cells.

(A) Coomassie-blue stained gel. Lane 1, protein mass markers; lane 2, proteins extracted from normal B. mori cells; lane 3, proteins extracted from B. mori cells infected by recombinant virus. (B) Western blot with anti His-tag antibodies. crotome and then stained with uranyl acetate and lead citrate for examination under a transmission electron microscope (TEM).

Flow cytometric analysis. The hepatoma cells treated with 20,40 , and $80 \mu \mathrm{g} / \mathrm{mL}$ of recombinant PTA and the control cells were collected by centrifugation at $1000 \mathrm{rpm}$ for $5 \mathrm{~min}$ at $4^{\circ} \mathrm{C}$. The cells were then resuspended in cold PBS and fixed with $70 \%$ ethanol for $24 \mathrm{~h}$ at $-20^{\circ} \mathrm{C}$. The fixed cells were centrifuged, resuspended in PBS containing $100 \mu \mathrm{g} / \mathrm{mL}$ DNase-free RNase A, and incubated at $37^{\circ} \mathrm{C}$ for $30 \mathrm{~min}$. After adding propidium iodide $(\mathrm{PI})$ to the final concentration of $10 \mu \mathrm{g} /$ $\mathrm{mL}$ and incubation at $37^{\circ} \mathrm{C}$ for $30 \mathrm{~min}$ in dark, the samples were analyzed with flow cytometry (FACSCalibur, BD) and data were analyzed with Data Analysis System.

Statistical analysis. All data and results presented were confirmed in at least three independent experiments. Data were presented as mean \pm S.D. and analyzed with SPSS 13.0 software. Statistical comparisons were made using a Student's t-test. $P<0.05$ was considered statistically significant.

\section{RESULTS}

The conserved gene from $P$. ternata that encodes an aroid mannose-binding agglutinin was cloned and a recombinant donor plasmid pFastBacHTA-pta was subsequently constructed. Gel electrophoresis in $0.8 \%$ agarose showed that the fragment of the cloned pta gene was about $800 \mathrm{bp}$ in length. The nucleotide sequence has been deposited, along with the predicted amino acid sequence, in GenBank (Accession No. JF293072). The data were searched in UniProt database and the deduced amino acid sequence of PTA was analyzed with Blastp. This sequence was compared with previously sequenced PTA (DB:ID Q6SRZ3), Pinellia pedatisecta agglutinin (DB:ID E2ITD6), A. heterophyllum agglutinin (DB:ID Q7Y0G6), T. divaricatum lectin (DB:ID A2ICN3), and Polygonatum cyrtonema lectin (DB:ID Q8L568), showing significant similarity, with $80 \%, 82 \%, 82 \%, 75 \%$ and $42 \%$ identity, respectively. A comparison of these lectins revealed that all contain the conserved motif 'QXDXNXVXY' (Fig. 1).

To express the gene cloned in B. mori cells, recombinant baculovirus containing the target gene fragment was constructed. Viral suspension was collected, verified through PCR, and stored at $4^{\circ} \mathrm{C}$. Electrophoresis for identification of recombinant virus showed that the lane using M13 forward and M13 reverse primers was about $2400 \mathrm{bp}$ larger than those using specific primers. This is theoretically concordant with more $2430 \mathrm{bp}$ than target gene. The recombinant baculovirus was submitted to the China General Microbiological Culture Collection Center (CGMCC No. 3677). 


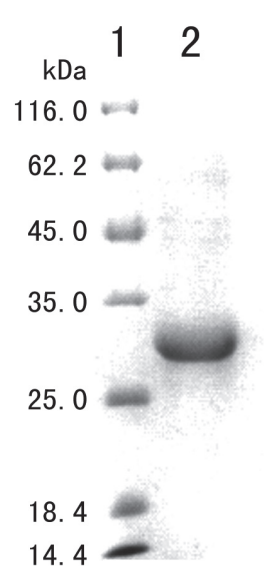

Figure 3. Purification of recombinant PTA from silkworm cells. Lane 1, protein mass markers; lane 2, purified His-tagged PTA.

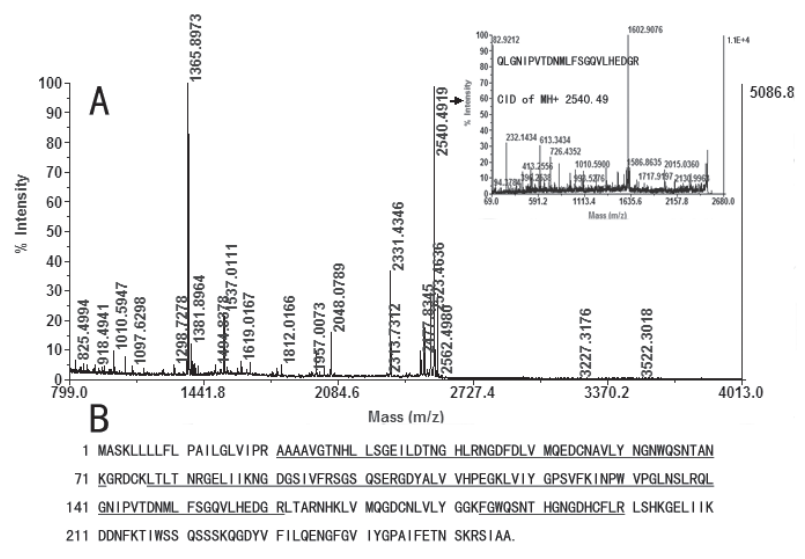

Figure 4. Analysis of rPTA by MALDI-TOF MS/MS.

(A) Peptide mass fingerprints of PTA and the MS/MS spectrum of peptide $\mathrm{m} / \mathrm{z} 2540.49$ confirmed from the labeled ions. (B) Amino acid sequence of PTA. Matched peptides is underlined.

After the B. mori cells were infected with the recombinant baculovirus, the expressed protein was analyzed and detected via SDS/PAGE and Western blotting. The target protein was detected in the infected cells, but not in the negative controls (Fig. 2). The expected molecular mass of the expressed protein was about 29 $\mathrm{kDa}$ (Fig. 2), based on the theoretical value.

Purification was carried out with an $\mathrm{Ni}^{2+}{ }_{-} \mathrm{NTA}$ system as there was a $6 \times$ His tag at the N-terminus of the recombinant protein. The purified protein exhibited a single band under 12\% SDS/PAGE (Fig. 3). The image of the gel analyzed using BandScan 5.0 program revealed that the purity of the products was approximately $94 \%$.

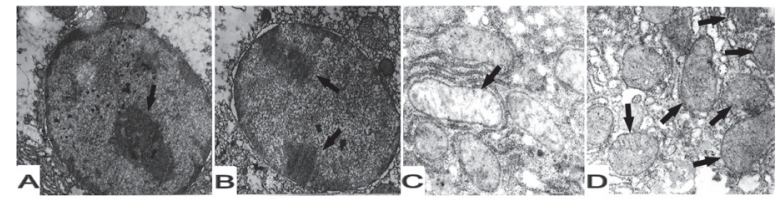

Figure 5. Effect of rPTA on hepatoma cell morphology. Hepatoma SMMC 7721 cells were incubated with $40 \mu \mathrm{g} / \mathrm{mL}$ rPTA, and ultrastructural changes were observed. (A, B) nucleus $\times 7000$; (C, D) mitochondrion $\times 20000$; (B) nucleus of treated cells; (D) $\mathrm{mi}^{-}$ tochondrions of treated cells; (A, C) represent controls.
To verify if the detected protein was PTA, the target band was excised from the gels and MALDI-TOF/ TOF was employed. The peptide mass fingerprints and MS/MS spectra of PTA are illustrated in Fig. 4. The fingerprint (Fig. 4) of the expressed protein was compared with the predicted amino acid sequence of PTA using ProteinProspector Tools (http://prospector.ucsf. edu/prospector/mshome.htm). Nine of the peak values of the peptide mass fingerprint matched the predicted values. Thus, confirming the identification of the purified protein.

A hemagglutination activity assay was conducted in $\mathrm{V}$ bottomed 96-well microtiter plates in a final volume of $100 \mu \mathrm{L}$ containing $50 \mu \mathrm{L}$ of a $2 \%$ suspension of rabbit erythrocytes previously washed three times in $0.9 \%$ sodium chloride solution, and $50 \mu \mathrm{L}$ of a two-fold serial dilution of recombinant PTA. After the mixtures were incubated at room temperature for $1.5 \mathrm{~h}$, the cells were observed under an inverted microscope. The cells were obviously agglutinated (Fig. S1, at www.actabp.pl), and the minimum rPTA concentration required to agglutinate rabbit erythrocytes was $3.25 \mu \mathrm{g} / \mathrm{mL}$.

Inhibition of the hemagglutinating activity by several sugars (1,4- $\beta$-D-mannan, D-mannose, and D-glucose) was examined by adding two-fold serial dilutions of the sugars to the incubation mixtures as above. The results showed that the agglutination activity of rPTA can be inhibited by 1,4- $\beta$-D-mannan at a final concentration of $0.2 \mathrm{mM} / \mathrm{L}$, D-mannose at $70 \mathrm{mM} / \mathrm{L}$, but not by D-glucose when its final concentrations up to $450 \mathrm{mM} / \mathrm{L}$.

To determine the effects of the rPTA on cancer cells, human hepatoma cells were treated with the protein solution and their morphology was then observed. After $48 \mathrm{~h}$, the treated cells exhibited shrinkage, blebbing, and loss of attachment as observed under an inverted phasecontrast microscope. Observation of the ultrastructure of the cells under a TEM $(\times 7000)$ revealed that the nuclei of the treated cells showed typical morphological changes, including chromatin condensation and aggregation at the inner surface of the nuclear membrane (Fig. 5B). Nuclei of control cells were normal (Fig. 5A). Most of the mitochondria $(\times 20000)$ from cells treated with the rPTA exhibited swelling and their cristae were disorganised (Fig. 5D). The mitochondrial morphology in the control cells was normal (Fig. 5C).

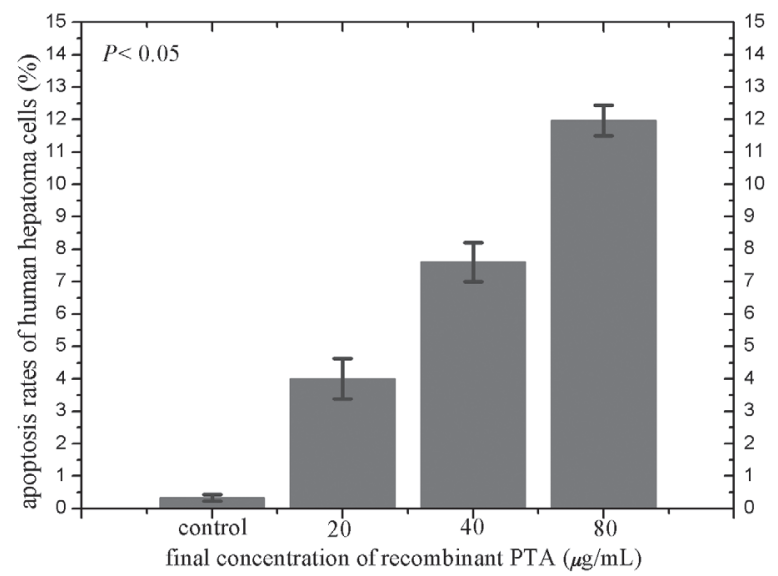

Figure 6. Apoptosis rates of human hepatoma SMMC7721 cells treated with 20,40 , and $80 \mu \mathrm{g} / \mathrm{mL}$ rPTA for $48 \mathrm{~h}$.

Control indicates the apoptosis rate of untreated cells. Error bars indicate standard deviations obtained from three independent experiments. 
When the cells were analyzed by flow cytometry, typical apoptotic peaks were observed for treated cells (Fig. S2, at www.actabp.pl). Cells treated with rPTA at different final concentrations for $48 \mathrm{~h}$ exhibited different apoptosis rates which were obviously higher than that in the control group (Fig. 6). The $t$-test result revealed that the differences in the apoptosis rates of the cells treated with different protein concentrations, including the controls, were statistically significant $(P<0.05)$. This suggests that rPTA inhibited the cancer cell proliferation in a dose-dependent manner.

\section{DISCUSSION}

To date, several studies have proven that baculoviruses are very effective and versatile vectors for expressing heterologous proteins in baculovirus-infected insect cells (Chen et al., 2006). In the early 1980s, the B. mori nuclear polyhedrosis virus (BmNPV) was introduced as a viral vector for protein expression (Maeda et al., 1985). Nowadays, B. mori and its cells have been used as bioreactors to produce many important biomedical proteins because they can be cultured easily at low cost and the protein undergoes proper post-translational processing in silkworm cells (Deng et al., 1995; Gong et al., 2005; Chen et al., 2006). Biomedical proteins such as bone morphogenetic protein 2 , endostatin, calcitonin, angiostatin, osteoprotegerin, lactoferrin, and hGM-CSF, which have been previously expressed in our laboratory, displayed the same biologic activity as the human proteins produced in mammalian systems (Chen et al., 2006). However, there are very few reports about plant proteins produced in this system. In the current study, we first reported PTA expression in B. mori cells using the Bac-to-Bac/BmNPV baculovirus expression system.

P. ternata, a traditional Chinese medicine, has a long history of use as a treatment for tumors. Its allied species Pinellia pedatisectae is often mistaken for P. ternata in China due to their morphologic similarities. A previous study has shown that $P$. pedatisectae agglutinin (PPA) is highly similar to other monocot mannose-binding lectins in terms of amino acid sequence. It specifically had the highest identity with PTA (Lin et al., 2006), which is consistent with the result of the amino acid sequence analysis in the current study. These sequences are highly conserved in the mannose-binding motif (QXDXNXVXY) (Fig. 1). As shown in Fig. 1, with a deletion of thirteen amino acids on the C-terminal part of the PTA (DB:ID Q6SRZ3), the peptide is almost identical to PPA (DB:ID E2ITD6) and $A$. heterophyllum agglutinin (AHA) (DB:ID Q7Y0G6). The hemagglutination activity of refolded PPA expressed in E. coli against rabbit erythrocytes was nearly fourfold that of PTA expressed in E. coli. (Liang et al., 2009). This difference could be due to the diverged third mannose-binding motif, which differs by four amino acids; between the two proteins, or to the thirteen amino acids absent on the C-terminus of PTA, which may affect the three-dimensional conformation (Barre et al., 1996). In the present study, a conserved aroid mannose-binding agglutinin gene was cloned from $P$. ternata tubers and expressed in B. mori cells. The hemagglutination assay revealed that the activity of the PTA expressed in B. mori cells was nearly twice that of PTA previously expressed in E. coli by Ling et al. The inhibitory effect of D-mannan and D-mannose showed that the biological activities of the rPTA are due to its carbohydrate-binding activity. The relatively higher hemagglutination activity may be due to the correct fold- ing of the expressed protein in the B. mori cells, as well as post-translational modifications.

Numerous plant lectins, especially monocot mannosebinding lectins, possess anti-tumor activities because they can interact with the complex carbohydrates on the cell membrane of these cancer cell lines. T. divaricatum lectin (TDL) (DB:ID A2ICN3) has high homology with PTA. They have three highly conserved mannose-binding motifs (Fig. 1). Luo, et al. extracted a mannose-binding lectin from fresh tubers of $T$. divaricatum (L.) Decne, a plant belonging to the Araceae family. TDL showed cytotoxicity against prostatic carcinoma Pro-01 and mastocarcinoma Bre-04, and minor inhibitory effects against lung cancer Lu-04. However, there was no significant anti-proliferative effect on HepG2 and HeLa cells. The difference in the inhibition of proliferation is probably because of the different terminal sugars in the various tumor cell lines (Luo et al., 2007). Polygonatum cyrtonema lectin (PCL) (DB:ID Q8L568) is also highly similar to PTA, with two of the three highly conserved mannosebinding motifs. PCL is reportedly cytotoxic to cancer cells and induces their apoptosis. It can upregulate Bax and downregulate $\mathrm{Bcl}-\mathrm{xL}$ and $\mathrm{Bcl}-2$, which lead to mitochondrial depolarization, cytochrome release, and caspase activation (Liu et al., 2009). In the current study, the anti-proliferative activity of PTA expressed in B. mori cells was determined. Tumor cells treated with PTA showed signs of apoptosis (Fig. 5). The flow cytometric results also suggest that PTA induced apoptosis in a dosedependent manner (Fig. 6). The mitochondrial swelling possibly indicates that PTA induces apoptosis through a mitochondria-mediated pathway (Fig. 5). The results of the current study indicate that the PTA expressed by the B. mori cells possesses anti-proliferative activity on human hepatoma cells in vitro. The exact molecular mechanisms of the anti-proliferative effects of PTA on cancer cells require further investigation.

The protein expressed by B. mori cells is, unfortunately, expensive to produce. However, the plant lectin could be produced in B. mori pupae and larvae, which could solve this problem.

In summary, PTA gene was successfully expressed in B. mori cells. This was the first time that PTA was expressed in the BmNPV expression system. Silkworm pupae and larvae can therefore be used as a bioreactor for producing PTA and other plant lectins. Silkworm may be a practical tool for expressing many other important medicinal proteins.

\section{Acknowledgements}

This research was supported by the National Natural Science Fund of China (No. 30772712) and the National High Technology Research and Development Program (No. 2011AA100603).

\section{REFERENCES}

Abdullaev FI, de Mejia EG (1997) Antitumor effect of plant lectins. Natural Toxins 5: 157-163

Bains JS, Dhuna V, Singh J, Kamboj SS, Nijiar KK, Agrewala JN (2005) Novel lectins from rhizomes of two Acorus species with mitogenic activity and inhibitory potential towards murine cancer cell lines. Int Immunopharmacol 5: 1470-1478.

Barre A, Van Damme EJM, Peumans WJ, Rouge P (1996) Structurefunction relationship of monocot mannose-binding lectins. Plant Physiol 112: 1531-1540.

Chen J, Wu XF, Zhang YZ (2006) Expression, purification and characterization of human GM-CSF using silkworm pupae (Bombyx mori) as a bioreactor. J Biotechnol 123: 236-247.

Consortium TISG (2008) The genome of a lepidopteran model insect, the silkworm Bombyx mori. Insect Biochem Mol Biol 38: 1036-1045. 
De Mejía EG, Prisecaru VI (2005) Lectins as bioactive plant proteins: a potential in cancer treatment. Crit Rev Food Sci Nutr 45: 425-445.

Deng J, Wang S, Yang Q, Cheng X, Li L (1995) High-level expression of human beta-interferon gene in the silkworm with new constructed BmNPV vector. Chin J Biotechnol 11: 109-117.

Dhuna V, Bains JS, Kamboj SS, Singh J, Kamboj S, Saxena AK (2005) Purification and characterization of a lectin from Arisaema tortuosum Schott having in-vitro anticancer activity against human cancer cell lines. J Biochem Mol Biol 38: 526-532.

Gao X, Tian HY, Liu L, Yu ML, Jing NH, Zhao FK (2009) Comparative proteomic analysis of proteins involved in cell aggregation during neural differentiation of P19 mouse embryonic carcinoma cells. $J$ Proteome Res 8: 1765-1781.

Gong Z, Jin Y, Zhang Y (2005) Oral administration of a cholera toxin $\mathrm{B}$ subunit-insulin fusion protein produced in silkworm protects against autoimmune diabetes. J Biotechnol 119: 93-105.

Hamelryck TW, Loris R, Bouckaert J, Dao-Thi MH, Strecker G, Imberty A, Fernandez E, Wyns L, Etzler ME (1999) Carbohydrate binding, quaternary structure and a novel hydrophobic binding site in two legume lectin oligomers from Dolichos biflorus. J Mol Biol 286: 1161-1177.

Inoue S, Kanda T, Imamura M, Quan GX, Kojima K, Tanaka H, Tomita M, Hino R, Yoshizato K, Mizuno S, Tamura T (2005) A fibroin secretion-deficient silkworm mutant, Nd-sD, provides an efficient system for producing recombinant proteins. Insect Biochem Mol Biol 35: 51-59.

Kaku H, Van Damme EJ, Peumans WJ, Goldstein IJ (1990) Carbohydrate-binding specificity of the daffodil (Narcissus pseudonarcissus) and amaryllis (Hippeastrum bybr.) bulb lectins. Arch Biochem Biophys 279: 298-304.

Karasaki Y, Tsukamoto S, Mizusaki K, Sugiura T, Gotoh S (2001) A garlic lectin exerted an antitumor activity and induced apoptosis in human tumor cells. Food Res Int 34: 7-13.

Kaur M, Singh K, Rup PJ, Kamboj SS, Saxena AK, Sharma M, Bhagat M, Sood SK, Singh J (2006a) A tuber lectin from Arisaema jacquemontii Blume with anti-insect and anti-proliferative properties. $J$ Biochem Mol Biol 39: 432.

Kaur M, Singh K, Rup PJ, Saxena AK, Khan RH, Ashraf MT, Kamboj SS, Singh J (2006b) A tuber lectin from Arisaema belleborifolium Schott with anti-insect activity against melon fruit fly, Bactrocera cucurbitae (Coquillett) and anti-cancer effect on human cancer cell lines. Arch Biochem Biophys 445: 156-165.

Li XH, Wang D, Zhou F, Yang HJ, Bhaskar R, Hu JB, Sun CG, Miao YG (2010) Cloning and expression of a cellulase gene in the silkworm, Bombyx mori by improved Bac-to-Bac/BmNPV baculovirus expression system. Mol Biol Rep 37: 3721-3728.

Liang JL, Cheng B, Tian X, Liu XC (2009) Prokaryotic expression and characteristics research of pinellia ternata and pinellia pedatisectae lectins. China Biotechnol 29: 80-84.

Lin J, Zhou X, Fei J, Liao Z, Jin W, Sun X, Tang K (2006) Genomic cloning and characterization of a PPA gene encoding a mannosebinding lectin from Pinellia pedatisecta. Biocell 30: 15-25.

Ling LJ, Yang YZ, Bi YR (2010) Expression and characterization of two domains of Pinellia ternata agglutinin (PTA), a plant agglutinin from Pinellia ternata with antifungal activity. World I Microbiol Biotechnol 26: 545-554.

Liu B, Cheng Y, Zhang B, Bian H, Bao J (2009) Polygonatum cyrtonema lectin induces apoptosis and autophagy in human melanoma A375 cells through a mitochondria-mediated ROS-p38-p53 pathway. Cancer Lett 275: 54-60.

Liu B, Bian H, Bao J (2010) Plant lectins: Potential antineoplastic drugs from bench to clinic. Cancer Lett 287: 1-12.
Luo Y, Xu X, Liu J, Li J, Sun Y, Liu Z, Van Damme E, Balzarini J, Bao J (2007) A novel mannose-binding tuber lectin from Typhonium divaricatum (L.) Decne (family Araceae) with antiviral activity against HSV-II and anti-proliferative effect on human cancer cell lines. $J$ Biochem Mol Biol 40: 358-367.

Maeda S, Kawai T, Obinata M, Fujiwara H, Horiuchi T, Saeki Y, Sato Y, Furusawa M (1985) Production of human alpha-interferon in silkworm using a baculovirus vector. Nature 315: 592-594.

Miao Y, Zhang Y, Nakagaki K, Zhao T, Zhao A, Meng Y, Nakagaki M, Park EY, Maenaka K (2006) Expression of spider flagelliform silk protein in Bombyx mori cell line by a novel Bac-to-Bac/BmNPV baculovirus expression system. Appl Microbiol Biotechnol 71: 192-199.

Mo H, Rice KG, Evers DL, Winter HC, Peumans WJ, Van Damme EJM, Goldstein IJ (1999) Xanthosoma sagittifolium tubers contain a lectin with two different types of carbohydrate-binding sites. $J$ Biol Chem 274: 33300-33305.

Rostock M, Huber R, Greiner T, Fritz P, Scheer R, Schueler J, Fiebig $\mathrm{H}$ (2005) Anticancer activity of a lectin-rich mistletoe extract injected intratumorally into human pancreatic cancer xenografts. Anticancer Res 25: 1969-1975.

Sharon N, Lis H (2004) History of lectins: from hemagglutinins to biological recognition molecules. Glycobiology 14: 53R-62R.

Shevchenko A, Wilm M, Vorm O, Jensen O, Podtelejnikov A, Neubauer G, Mortensen P, Mann M (1996) A strategy for identifying gel-separated proteins in sequence databases by MS alone. Biochem Soc Trans 24: 893.

Singh J, Kamboj SS (2004) A novel mitogenic and antiproliferative lectin from a wild cobra lily, Arisaema flavum. Biochem Bbiophys Res Commun 318: 1057-1065.

SinghBains J, Singh J, Kamboj SS, Nijjar KK, Agrewala JN, Kumar V, Kumar A, Saxena A (2005) Mitogenic and anti-proliferative activity of a lectin from the tubers of Voodoo lily (Sauromatum venosum) Biochim Biophys Acta (BBA)-General Subjects 1723: 163-174.

Trigueros V, Wang M, Pere D, Paquereau L, Chavant L, Fournier D (2000) Modulation of a lectin insecticidal activity by carbohydrates. Arch Insect Biochem Physiol 45: 175-179.

Van Damme EJ, Goossens K, Smeets K, Van Leuven F, Verhaert P, Peumans WJ (1995) The major tuber storage protein of araceae species is a lectin (characterization and molecular cloning of the lectin from Arum maculatum L.) Plant Physiol 107: 1147.

Van Damme EJ, Nakamura-Tsuruta S, Smith DF, Ongenaert M, Winter HC, Rougé P, Goldstein IJ, Mo H, Kominami J, Culerrier R, Barre A, Hirabayashi J, Peumans WJ (2007) Phylogenetic and specificity studies of two-domain GNA-related lectins: generation of multispecificity through domain duplication and divergent evolution. Biochem J 404: 51-61.

Wong R, Sagar SM (2010) Supportive Cancer Care Using Chinese Medicine. Supp Cancer Care Chinese Med: 1-37.

Xia Q, Zhou Z, Lu C, Cheng D, Dai F, Li B, Zhao P, Zha X, Cheng $T$, Chai C (2004) A draft sequence for the genome of the domesticated silkworm (Bombyx mori) Science 306: 1937-1940.

Yue W, Miao Y, Li X, Wu X, Zhao A, Nakagaki M (2006) Cloning and expression of manganese superoxide dismutase of the silkworm, Bombyx mori by Bac-to-Bac/BmNPV Baculovirus expression system. Appl Microbiol Biotechnol 73: 181-186.

Zhou L, Wu X, Lan L, Liu J (2009) Expression of Trichoderma reesei endo-beta-glucanase II in silkworm, Bombyx mori L. by using BmNPV/Bac-to-Bac expression system and its bioactivity assay. Biotechnol Lett 32: 67-72. 